\title{
Acacia auriculiformis Cunn. Ex Benth As Phytoextraction Agent: A Growth Response, Physiological Tolerance and Lead Removal Capability Evaluation
}

\author{
Abderrahmane Zerkout, Muskhazli Mustafa*, Hishamuddin Omar, Mohd Hafiz \\ Ibrahim and Rusea Go
}

Department of Biology, Faculty of Science, Universiti Putra Malaysia, 43400 UPM Serdang Selangor, Malaysia

Received: July 9, 2020; Revised: October 15, 2020; Accepted: November 14, 2020

\begin{abstract}
This study was conducted to determine A. auriculiformis capability to tolerate elevated $\mathrm{Pb}$ concentration. The uptake, distribution, and the capability of $A$. auriculiformis plant to remove lead $(\mathrm{Pb}) \mathrm{Pb}$ from the soil was assessed, as well as the growth performance, and some physiological parameters of the plant. The results revealed that $\mathrm{Pb}$ toxicity has no effect on A. auriculiformis plant growth up to $1 \mathrm{~g} / \mathrm{kg}$ of soil, with the maximum amount of $\mathrm{Pb}$ absorbed in soil treated with $1 \mathrm{~g} / \mathrm{kg}$ of $\mathrm{Pb}$. The bioconcentration factor (BCF), and translocation factor (TF) values were 0.78 and 3.55 respectively, indicating that A. auriculiformis is an ideal phytoremediator for soils containing $1 \mathrm{~g} / \mathrm{kg} \mathrm{Pb}$. In conclusion, A. auriculiformis exposed to high $\mathrm{Pb}$ concentration (1 g/kg of soil) showed good growth and development, thereby a high tolerance capacity, so it is a suitable candidate for $\mathrm{Pb}$ phytoremediation over the short or medium term.
\end{abstract}

Keywords: Proline, Catalase, transpiration rate, net photosynthesis, bioconcentration factor, translocation factor

\section{Introduction}

The exploitation of various types of deposits in the underground lead $(\mathrm{Pb})$ to the accumulation of $\mathrm{Pb}$ on the surface which has an effective effect on plant growth and development (Adhikari et al., 2014). Extensive researches have been conducted on the early stages of plants' growth and how they can be affected by heavy metals in order to help distinguish species that are heavy metal-tolerant which is crucial for this field of study as with nowadays pollution, the phytoremediation of polluted sites from toxic heavy metals is unescapable (Ali et al., 2013). The high concentration of $\mathrm{Pb}$ intervenes various plant physiological process and development such as photosynthesis, mineral nutrition, sugar transport, seedling growth and seed germination (Zerkout et al. 2018).

It has been reported that plants are able to manipulate the heavy metal from the soil by restoring it in their roots (Masvodza et al., 2013; Majid et al., 2012; Ochonogor and Atagana, 2014). Phytoremediation has become the way out to extract heavy metal properly without affecting the environment and potentially cost-effective (Illié et al., 2015), especially the phytoextraction technique. Phytoextraction is an important aspect of phytoremediation; it consists especially of the extraction of heavy metals from soil and storing them in roots, shoots and leaves (Souza et al., 2013). One disadvantage of using this technique is that it takes a longer time than other treatments, due to plant limitation, where in most cases high contaminant concentration can reduce the speed of plant growth (Meriem et al., 2015; Ali et al., 2013; Moosavi and Seghatoleslami, 2013). However, fast growing and high heavy metal tolerance plant has been used, which requires an intensive search to identify the potential plant. The choice of phytoremediation candidates is important. Some plants can be short-lived, too small to be significant as pool to contain heavy metals or serve as food for herbivores. Ideal phytoremediation agents should be a hardy plant, long-lived, fast growing, big and inedible.

Acacia plants fit the above description perfectly, they are adapted to a wide range of environments, both tropical and temperate, and this adaptability has made them popular for planting on degraded lands in Asia and elsewhere (Turnbull et al., 1997). Acacia spp. have the potential to rehabilitate the soil through absorption and storage of heavy metals their leaves, shoots and roots which makes them the best phytoremediation candidates (Veronica et al., 2011). Ex-situ studies using seedling have shown that Acacia sp. is able to tolerate and accumulate heavy metals in a different part of the plant (Majid et al., 2012; Mahdavi et al., 2014). In situ studies using Acacia sp. have also been reported, such as the use of A. saligna and $A$ polyacantha at the gold mine area in Zimbabwe (Masvodza et al., 2013). In Malaysia, several studies using Acacia mangium in ex-tin mine (Ahmad Zuhaidi and Jeyanny, 2018), gold mine (Ahmad Zuhaidi et al., 2018) and sewage disposal site (Mohd et al., 2013) had shown a positive response, especially in translocation of Aluminium ( $\mathrm{Pb})$, Ferum (Fe), Zinc, $(\mathrm{Zn})$ Copper $(\mathrm{Cu})$ and Cadmium (Cd). However, A. auriculiformis has not been

\footnotetext{
* Corresponding author e-mail: muskhazli@upm.edu.my.
} 
tested or reported as phytoremediation agent. Therefore, it is necessary to study other Acacia plants that can resist higher concentrations and have similar phytoremediation properties.

Acacia auriculiformis can be a potential candidate in this matter as it produces high biomass yield and well adapts to degraded or poor soil conditions (Sofea et al., 2017). It is a fast-growing multipurpose tree species in the Leguminosae family that can reach $30 \mathrm{~m}$ of height and 30 $\mathrm{cm}$ of diameter (Turnbull et al., 1997). However, phytoremediation using A. auriculiformis species on $\mathrm{Pb}$ contaminated soils has never been reported. Based on the attributes mentioned, theoretically, A. auriculiformis should be able to tolerate, absorb and accumulate a large amount of $\mathrm{Pb}$ from the soil providing a perfect remediation technique to clean up $\mathrm{Pb}$ from the soil.

Therefore, the current study was conducted:

I.to examine the capability of A. auriculiformis plants to tolerate elevated $\mathrm{Pb}$ concentration,

II.to evaluate the uptake and distribution of $\mathrm{Pb}$ in different parts of the plant, and;

III.to determinate the capability of A. auriculiformis plant to remove $\mathrm{Pb}$ from the soil.

\section{Materials and Methods}

\subsection{Growth parameters measurement}

Germinated seeds were planted in plastic polybags containing a mixture of topsoil and sand, which were artificially spiked with different $\mathrm{Pb}$ concentrations (ranging from 0 to $3 \mathrm{~g} / \mathrm{kg}$ soil) under ambient conditions (Srinivas et al., 2013). The pants were arranged in a completely randomised design, and normal watering was performed every 2 days. Physical growth parameters such as shoot height, leaves number, basal diameter, and root length were measured every 3 weeks for a period of 90 days.

\subsection{Physiological parameters measurement}

Several selected different physiological parameters were measured to determine the plant's physiological response to $\mathrm{Pb}$ occurrence in soil. Net photosynthesis, total chlorophylls, internal $\mathrm{CO}_{2}$ concentration, transpiration rate and water use efficiency (WUE) were measured directly from the plant leaves using a portable photosynthesis system LI-6400 according to Liu et al., (2014) and Sinclair et al., (1984).

Cell membrane integrity was estimated by measuring the electrolytic conductivity using a conductometer (Pike et al., 1998) by comparing the electrolytic conductivity of fresh leaves submerge in stirred distilled water (EC1) and the electrolytic conductivity of the same sample after heated for 1 hour at $95{ }^{\circ} \mathrm{C} \pm 0.5{ }^{\circ} \mathrm{C}$ (EC2). Membrane integrity (\%) was based on the ratio between EC1 and EC2.

The relative water content (RWC) was determined based on method by Scippa et al., (2004) following the formula:

$$
\text { RWC }(\%)=[(F W-D W) /(\text { TW - DW })] \times 100
$$

Where FW is the leave fresh weight; TW is the turgescence weight (TW) and DW is the dry weight (DW).

\subsection{Proline and Catalase enzyme activities}

The proline or pyrrolidine 2-carboxylic acid was measured using Troll and Lindsay's (1955) method modified by Magné and Larher (1992). This technique is based on the proline's ability to react in acid and hot environments with ninhydrin to give a pink-coloured compound soluble in organic solvents such as toluene. The optical density of the samples was determined by spectrophotometry at a length of $520 \mathrm{~nm}$. The standard curve was constructed using the series of proline concentrations prepared from a stock solution of $10 \mu \mathrm{g} / \mathrm{ml}$.

Catalase activity (CAT) was determined as previously described by Weydert and Cullen (2009). Catalase activity was measured by monitoring the decrease in absorbance at $240 \mathrm{~nm}$ resulting from the decomposition of hydrogen peroxide $\left(\mathrm{H}_{2} \mathrm{O}_{2}\right.$.). One unit of catalase activity was defined as the amount of enzyme necessary to decompose 1 $\mu \mathrm{mol} / \mathrm{min} \mathrm{H}_{2} \mathrm{O}_{2}$ in $60 \mathrm{~s}$ at $25^{\circ} \mathrm{C} \pm 0.5^{\circ} \mathrm{C}$. The quantity of CAT is calculated based on the molar extinction coefficient $\Sigma=40 \mathrm{mM}_{-}{ }^{1} . \mathrm{cm}^{-1}$.

\subsection{Quantification of $\mathrm{Pb}$ in plant parts.}

The direct aqua regia method by McGrath and Cunliffe (1995) was used for the analyses of $\mathrm{Pb}$ concentrations in the samples. The $\mathrm{Pb}$ concentration in the sample was determined by using an air/acetylene (2.5: $15.0 \mathrm{~L} / \mathrm{min}$ ) flame atomic absorption spectrophotometer (AAS) at wavelengths of $283.31 \mathrm{~nm}$ (Lakshmi et al., 2015).

\subsection{Quantification of macronutrients in Acacia auriculiformis plants}

Root sample solution was prepared as recommended by Abuye et al., (2003) and quantification of macronutrient in the solution was then analysed by using air/acetylene (2.5: $15.0 \mathrm{~L} / \mathrm{min}$ ) flame atomic absorption spectrophotometer (AAS) at wavelengths of $239.856 \mathrm{~nm}$ for Calcium (Ca), $202.588 \mathrm{~nm}$ for Magnesium (Mg), $404.414 \mathrm{~nm}$ for Nitrogen (N), $213.618 \mathrm{~nm}$ for (P), and $766 \mathrm{~nm}$ for Potassium (K) (Silvana et al., 2010).

\subsection{Determination of $\mathrm{Pb}$ removal factor}

To examine the ability of the plant to accumulate $\mathrm{Pb}$ with respect to its concentration in the soil and plant potential to transfer metals from the roots to shoots and leaves, the bioconcentration factor (BCF) and the translocation factor (TF) were calculated based on the following equations 1 and 2, respectively (Majid et al., 2012):

$\mathrm{BCF}=\frac{[\mathrm{Pb} \text { concentration in plant tissue }]}{[\text { Initial concentration of } \mathrm{Pb} \text { in soil }]}$ (Equation 1)
$\mathrm{TF}=\frac{\mathrm{Pb} \text { concentration (stems +leaves) }}{\text { (Eq concentration (roots) }}$

\section{Results}

\subsection{The effect of $\mathrm{Pb}$ on A. auriculiformis growth parameters}

Figure 1 shows the effect of $\mathrm{Pb}$ concentrations on the growth parameters of $A$. auriculiformis plants after twelve weeks of growth. The growth parameters of $A$. auriculiformis seedlings in different treatments varied significantly compared to the control during the whole 
period of growth. There was no significant difference between the control treatment and the plants treated with 1 $\mathrm{g} / \mathrm{kg} \mathrm{Pb}$. However, plants grown in 2 and $3 \mathrm{~g} / \mathrm{kg} \mathrm{Pb}$-treated soil had more yellow and wilted leaves with smaller buds in comparison to the control.

After 3 weeks, plants grown in $1 \mathrm{~g} / \mathrm{kg}$ Pb-treated soil showed no significant difference compared to the control for all the measured parameters. Increasing the $\mathrm{Pb}$ concentration up $2 \mathrm{~g} / \mathrm{kg}$ Pb-treated soil had led to a decrease in the shoot height, basal diameter, leaves number and root length by $52 \%, 16 \%, 31 \%$ and $65 \%$, respectively compared to the control (Figure 2).

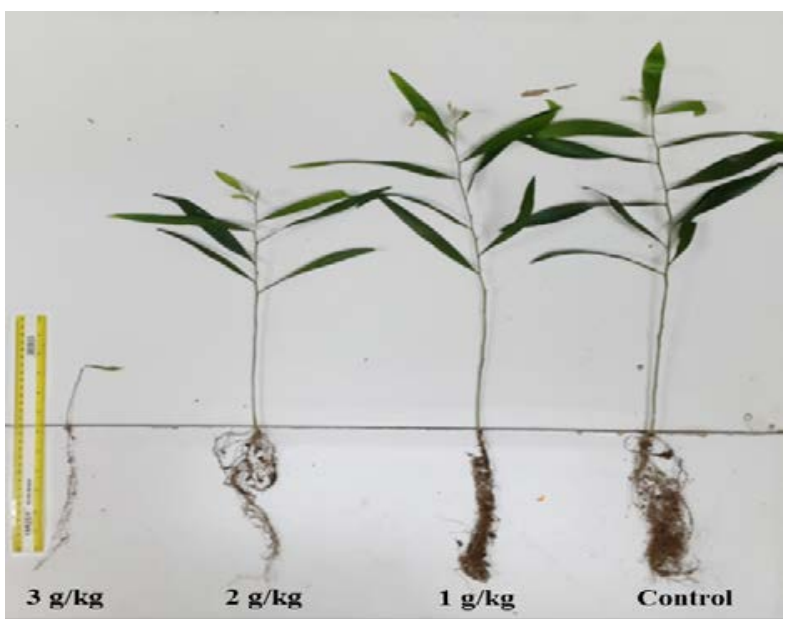

Lead had no effect on $A$. auriculiformis plant growth up to a concentration of $1 \mathrm{~g} / \mathrm{kg}$ Pb-treated soil, as there was no significant difference in the growth performance of $A$. auriculiformis seedlings between the control treatment and plants grown in $1 \mathrm{~g} / \mathrm{kg} \mathrm{Pb}$-treated soil.

\subsection{The effect of $\mathrm{Pb}$ on A. auriculiformis physiological parameters}

The effect of different $\mathrm{Pb}$ concentrations on some physiological parameters such as the net photosynthesis, total chlorophylls, transpiration rate, the internal $\mathrm{CO}_{2}$ concentration, water use efficiency (WUE) and the relative water content (RWC) in A. auriculiformis is shown in Table 1 . The $\mathrm{Pb}$ stress at $1 \mathrm{~g} / \mathrm{kg}$ and $2 \mathrm{~g} / \mathrm{kg} \mathrm{Pb}$-treated soil showed a reduction on net photosynthesis, total chlorophylls, transpiration rate and the internal $\mathrm{CO}_{2}$ concentration in A. auriculiformis compared to the control. The plant showed $\mathrm{Pb}$ stress at $1 \mathrm{~g} / \mathrm{kg}$ Pb-treated soil with decreased in WUE by $12 \%$ and the RWC by $15 \%$ significantly compared to the control. However, A. auriculiformis showed no significant difference between 1 $\mathrm{g} / \mathrm{kg}$ and $3 \mathrm{~g} / \mathrm{kg}$ Pb-treated soil for WUE and between 2 $\mathrm{g} / \mathrm{kg}$ and $3 \mathrm{~g} / \mathrm{kg} \mathrm{Pb}$-treated soil for RWC, thus indicating that the effect of $\mathrm{Pb}$ on $A$. auriculiformis physiological properties may vary depending on the concentration.

Figure 1. The effect of different $\mathrm{Pb}$ concentrations on shoot height, basal diameter, leaves numbers and root length of $A$. auriculiformis plants after twelve weeks of growth.

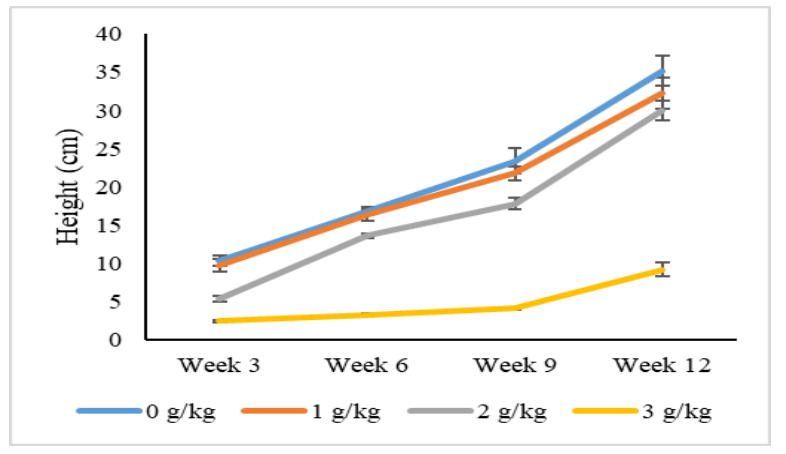

(a)

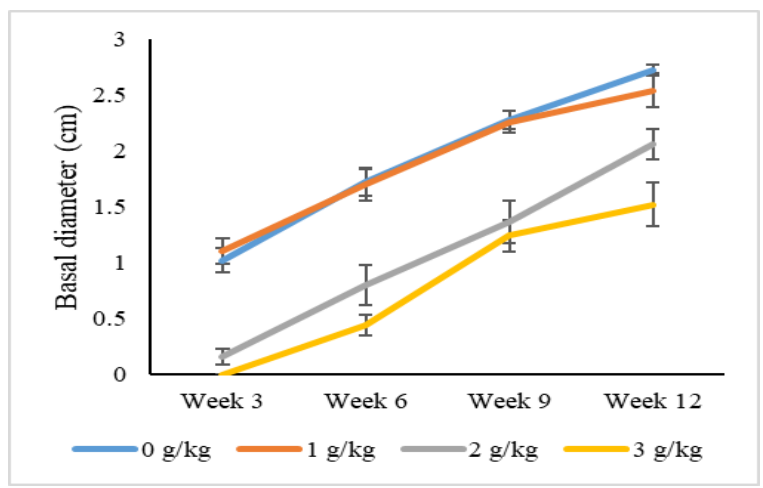

(c)

Figure 2. The effect of $\mathrm{Pb}$ on (a) the shoot height; (b) the leaves number; (c) the basal diameter and (d) the root length of A. auriculiformis plants.

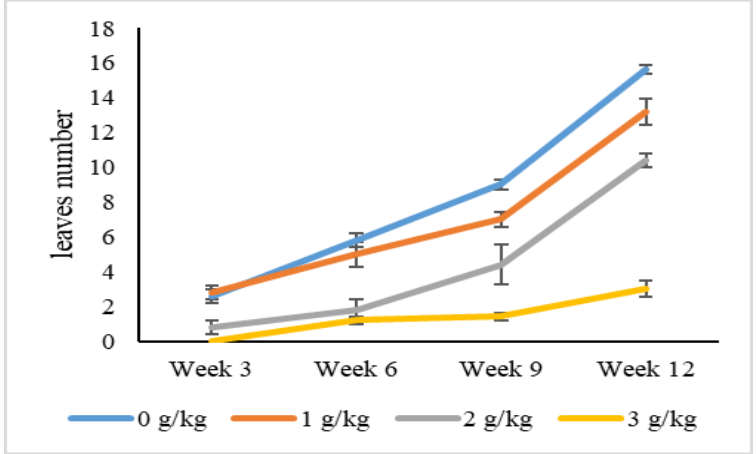

(b)

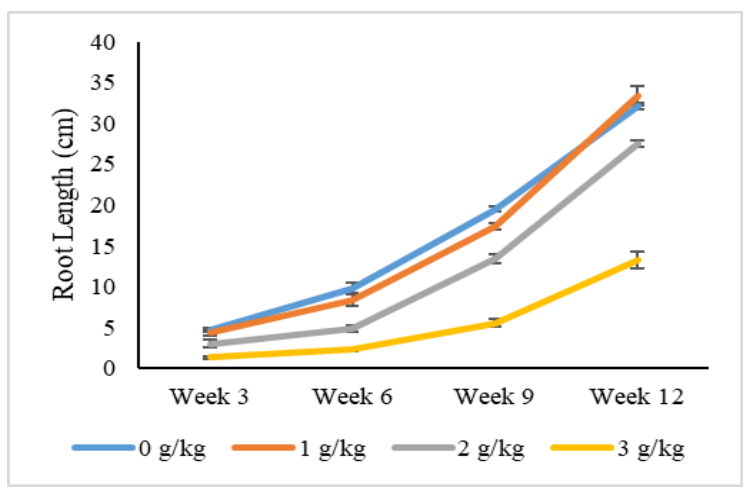

(d) 
Table 1. The effect of $\mathrm{Pb}$ on selected physiological properties in A. auriculiformis leaves after 90 days planted in soil supplemented with $\mathrm{Pb}$

\begin{tabular}{|c|c|c|c|c|c|c|}
\hline $\begin{array}{l}\mathrm{Pb} \\
(\mathrm{g} / \mathrm{kg})\end{array}$ & $\begin{array}{l}\text { Net Photosynthesis } \\
\left(\mathrm{Mmol} / \mathrm{M}^{2} / \mathrm{S}\right)\end{array}$ & Total Chlorophylls & $\begin{array}{l}\text { Internal } \mathrm{CO}_{2} \text { Concentration } \\
(\mathrm{mol} / \mathrm{mol})\end{array}$ & $\begin{array}{l}\text { Transpiration Rate } \\
\left(\mathrm{Mmol} / \mathrm{M}^{2} / \mathrm{S}\right)\end{array}$ & WUE & RWC \\
\hline$\overline{0}$ & $5.60 \pm 0.34^{\mathrm{a}}$ & $54.66 \pm 1.6^{\mathrm{a}}$ & $217.83 \pm 4.6^{\mathrm{a}}$ & $2.66 \pm 0.17^{\mathrm{a}}$ & $2.40 \pm 0.08^{\mathrm{a}}$ & $68.95 \pm 1.5^{\mathrm{a}}$ \\
\hline 1 & $3.59 \pm 0.19^{b}$ & $43.48 \pm 0.2^{\mathrm{b}}$ & $169.83 \pm 6.6^{\mathrm{b}}$ & $1.55 \pm 0.11^{\mathrm{b}}$ & $2.11 \pm 0.25^{\mathrm{b}}$ & $58.39 \pm 1.8^{b}$ \\
\hline 2 & $2.60 \pm 0.18^{c}$ & $41.83 \pm 0.3^{\mathrm{b}}$ & $169.17 \pm 4.5^{b}$ & $1.33 \pm 0.08^{\mathrm{b}}$ & $2.00 \pm 0.24^{\mathrm{b}}$ & $55.67 \pm 2.8^{c}$ \\
\hline 3 & $1.71 \pm 0.15^{\mathrm{d}}$ & $35.81 \pm 0.8^{\mathrm{c}}$ & $146.67 \pm 2.6^{\mathrm{c}}$ & $1.11 \pm 0.46^{\mathrm{c}}$ & $1.55 \pm 0.15^{\mathrm{c}}$ & $55.83 \pm 0.8^{c}$ \\
\hline
\end{tabular}

\subsection{Proline and Catalase response towards $\mathrm{Pb}$}

The results related to $\mathrm{Pb}$ effect on proline content in $A$. auriculiformis plant are shown in Figure 3a. The highest proline content was recorded in A. auriculiformis plant treated with $2 \mathrm{~g} / \mathrm{kg}$ Pb-treated soil $(1.40 \mathrm{mg} / \mathrm{ml})$ followed by $1 \mathrm{~g} / \mathrm{kg}$ Pb-treated soil $(0.87 \mathrm{mg} / \mathrm{ml})$. Increasing $\mathrm{Pb}$ concentration up to $3 \mathrm{~g} / \mathrm{kg}$ of soil had significantly decreased proline content to $0.13 \mathrm{mg} / \mathrm{ml}$. Proline accumulation in A. auriculiformis plants treated with 1 $\mathrm{g} / \mathrm{kg}$ and $2 \mathrm{~g} / \mathrm{kg} \mathrm{Pb}$-treated soil explained the high water content relatively close to the control (Table 4.1).

The effect of $\mathrm{Pb}$ on the catalase (CAT) activity in A. auriculiformis plant (Figure $3 \mathrm{~b}$ ), indicating that the $\mathrm{Pb}$ caused a significant overproduction of the CAT enzyme in A. auriculiformis plants grown in $1 \mathrm{~g} / \mathrm{kg} \mathrm{Pb}$-treated soil, which was the highest $\left(24.45 \mu \mathrm{mol} . \mathrm{min}^{-1} . \mathrm{mg}^{-1}\right.$ protein $)$, followed by plants grown in $2 \mathrm{~g} / \mathrm{kg}$ Pb-treated soil (22.35 $\mu \mathrm{mol} . \mathrm{min}^{-1} . \mathrm{mg}^{-1}$ protein). The lowest production of CAT enzyme was observed in plants grown in $3 \mathrm{~g} / \mathrm{kg} \mathrm{Pb}$-treated soil $\left(13.71 \mu \mathrm{mol} . \mathrm{min}^{-1} . \mathrm{mg}^{-1}\right.$ protein).

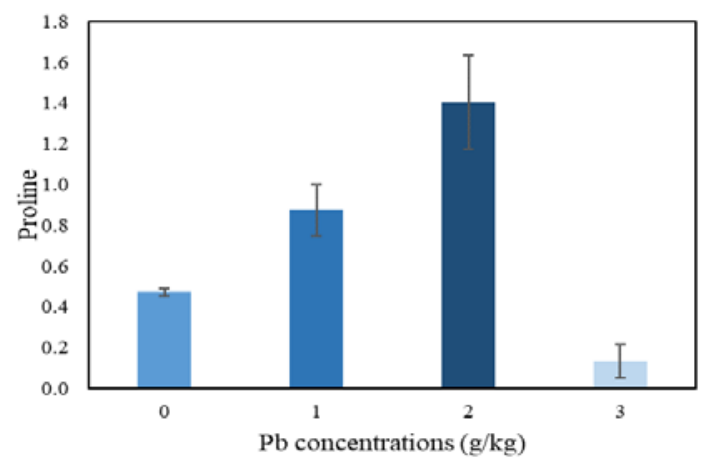

(a)

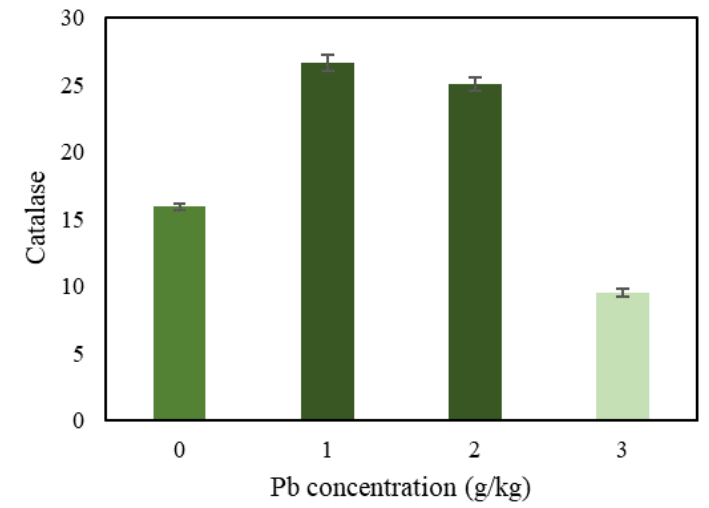

(b)

Figure 3. The effect of $\mathrm{Pb}$ on the (a) Proline and (b) Catalase activities in A. auriculiformis leaves.

\subsection{Pb storage capability in different part of plant}

Lead concentrations in the soil before and after planting A. auriculiformis were significantly influenced by $\mathrm{Pb}$ concentration (Figure 4a). Comparison of $\mathrm{Pb}$ concentration in soil between before and after A. auriculiformis planting showed that the lowest $\mathrm{Pb}$ reduction in soil was $0.28 \mathrm{~g}$ by control treatment, while the highest $\mathrm{Pb}$ concentration reduction was noted in the plants grown in $2 \mathrm{~g} / \mathrm{kg} \mathrm{Pb}$ treated soil followed by 1 and $3 \mathrm{~g} / \mathrm{kg}$ Pb-treated soil at 1.12 $\mathrm{g}, 0.95 \mathrm{~g}$ and $0.36 \mathrm{~g}$, respectively Lead was detected in all plant parts of A. auriculiformis, but its distribution was not equal across parts as illustrated in Figure 4b. Roots contained the highest $\mathrm{Pb}$ concentration compared to other parts, followed by shoots and leaves. In roots, plants grown in $2 \mathrm{~g} / \mathrm{kg} \mathrm{Pb}$-treated soil showed the highest $\mathrm{Pb}$ accumulation $(0.97 \mathrm{~g})$ followed by plants grown in $1 \mathrm{~g} / \mathrm{kg}$ and $3 \mathrm{~g} / \mathrm{kg} \mathrm{Pb}$-treated soil at $0.64 \mathrm{~g}$ and $0.60 \mathrm{~g}$, respectively.

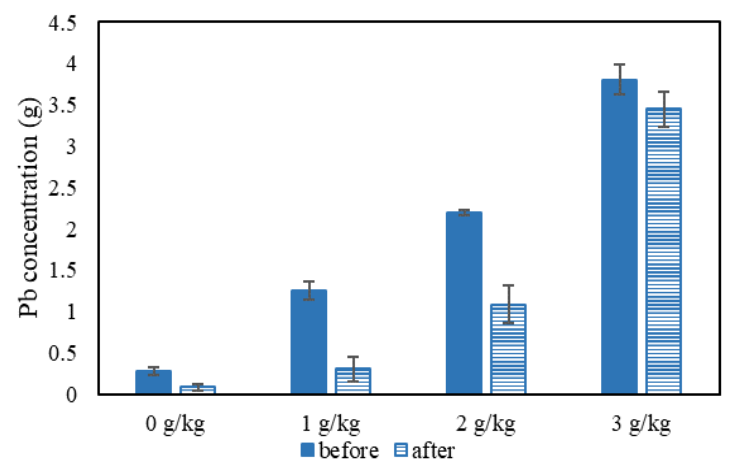

(a)

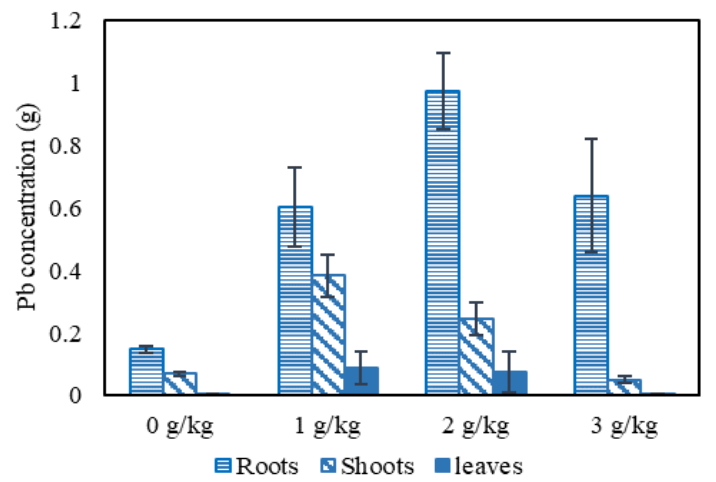

(b)

Figure 4. The concentration of $\mathrm{Pb}(\mathrm{a})$ in the soil before and after planting A. auriculiformis plant, and (b) in the different part of the plant.

\subsection{Impact of $\mathrm{Pb}$ on the distribution of macronutrients}

The effect of $\mathrm{Pb}$ on the distribution of selected macronutrients in A. auriculiformis plant is shown in Figure 5. It is clearly presented that $\mathrm{Pb}$ induced changes in the uptake of macronutrients by A. auriculiformis plant. Where in general, an increase in $\mathrm{Pb}$ concentration on soil 
had produced declined pattern in the distribution of micronutrient in A. auriculiformis. The results showed no significant difference in the macronutrients concentrations in plants grown in $1 \mathrm{~g} / \mathrm{kg} \mathrm{Pb}$-treated soil and the control treatment. The concentration of $2 \mathrm{~g} / \mathrm{kg} \mathrm{Pb}$-treated soil reduced the concentrations of $\mathrm{N}, \mathrm{P}$ and $\mathrm{K}$ by $77 \%, 60 \%$ and $48 \%$, respectively compared to the control, while Ca and $\mathrm{Mg}$ were relatively stable. The high concentration of $\mathrm{Pb}(3 \mathrm{~g} / \mathrm{kg})$ affects all macronutrients content in $A$. auriculiformis plant as the concentration of all macronutrient had been decreased compared to the control (88\% N, 86\% P, 48\% K, 19\% Ca and 80\% Mg).

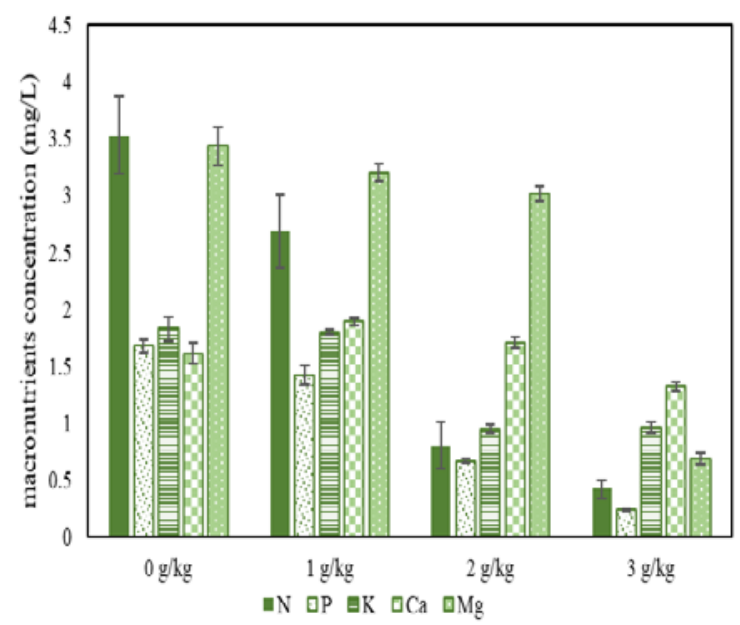

Figure 5. The effect of $\mathrm{Pb}$ toxicity on the absorption of macronutrients in Acacia auriculiformis plants.

\subsection{Evaluation on potential to absorb and accumulate} $\mathrm{Pb}$

The bioconcentration factor decreased gradually from 3.55 to 1.20 with increasing $\mathrm{Pb}$ concentration from $1 \mathrm{~g} / \mathrm{kg}$ to $2 \mathrm{~g} / \mathrm{kg}$ respectively (Figure 6). The bioconcentration factor was greater than one in all treatments $(\mathrm{BCF}>1)$ indicating the plant's capability to translocate $\mathrm{Pb}$ from the soil to the roots which suggests that $A$. auriculiformis is a potential candidate for $\mathrm{Pb}$ phytoremediation. The translocation factor (TF) in A. auriculiformis plant is shown in Figure 6. Plants grown in $1 \mathrm{~g} / \mathrm{kg}$ Pb-treated soil showed highest TF value (1.28) followed by plants grown in $2 \mathrm{~g} / \mathrm{kg}$ Pb-treated soil (0.33), whereas the lowest TF value was observed in plant grown in $3 \mathrm{~g} / \mathrm{kg}$ Pb-treated

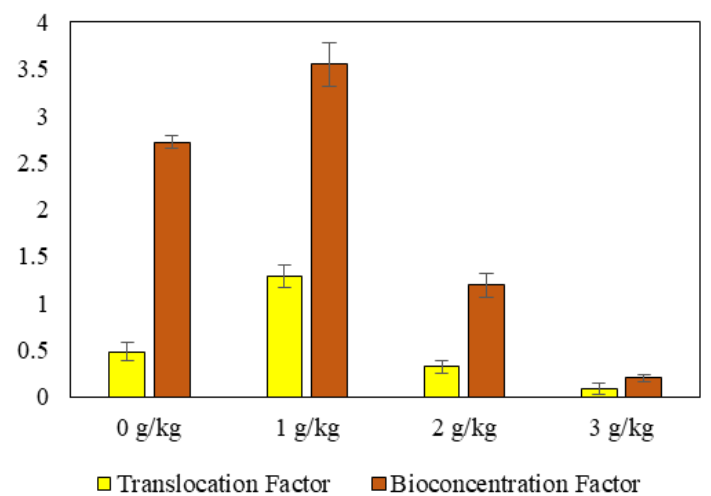
soil (0.08).

Figure 6. Values of the bioconcentration factor (BCF), and translocation factor (TF) in A. auriculiformis under different $\mathrm{Pb}$ concentration.

\section{Discussion}

Acacia auriculiformis seedlings grown in $1 \mathrm{~g} / \mathrm{kg} \mathrm{Pb}$ treated soil showed high tolerance toward $\mathrm{Pb}$ toxicity, and this tolerance is ensured by various defence systems responsible for capturing and neutralizing the metal, and for eliminating and replacing damaged molecules (Pan et al., 2011). These defence systems are usually present in the cytosol, and in different organelles, such as chloroplasts, mitochondria and peroxisomes (Del Rio et al., 2006). Plants grown in $2 \mathrm{~g} / \mathrm{kg}$ and $3 \mathrm{~g} / \mathrm{kg}$ Pb-treated soil showed symptoms of $\mathrm{Pb}$ toxicity, which was observed in a reduction of plant height, leaves number, basal diameter, and root length. These results are concurring with Kanwal et al., (2014) who found that high Pb doses reduced plant height and biomass, and long-term $\mathrm{Pb}$ exposure, even at non-lethal doses, led to necrosis at the root apex and leaves, as well as leaf chloroses. In the present study, all observed disturbances could be the result of $\mathrm{Pb}$ interaction with different cellular components and macromolecules, disrupting many physiological processes such as water status regulation, mineral nutrition, respiration, or photosynthesis (Ali et al., 2012). According to Muhammad et al., (2008) the reason for seedlings' high decrement could be the reduction in meristematic cells present in the shoot and some enzymes contained within the cotyledon and endosperms. When a metal is present in assimilable form and in very large quantities, the plant will be enriched with this metal, and above a certain rate, the plant metabolism will be reduced, the yield of the crop decreases and in extreme cases the death of the plant can occur (Ochonogor and Atagana, 2014).

The reduction in the selected physiological parameters had been observed in this study. The $\mathrm{Pb}$ toxicity had caused significant disruption on the biochemical pathway of the photosynthesis by distorting the chloroplast ultrastructure by either, (i) directly disrupting chlorophyll synthesis, plastoquinone and carotenoids via the inhibition of $\delta$-aminolevulinic acid dehydratase and protochlorophyllide reductase (Pereira et al., 2006; Tang et al., 2008), or (ii) acting on the transport of electrons and enzymes in Calvin cycle (Rubisco in particular) causing a reduction in the chlorophyll content (Chatterjee and Chatterjee, 2003). Subsequently, $\mathrm{Pb}$ can also be the main cause of deterioration of thylakoid and chloroplast structure and composition, leading to photosystems damage (Ali et al., 2012; Huang et al., 2013).

By closing the stomata, $\mathrm{Pb}$ considerably affects the electron transport chain, restricting gases exchange between the leaves and the atmosphere and leads to significant reduction in $\mathrm{CO}_{2}$ flow and fixation (Pourrut et al., 2011). Decreasing the fixation of $\mathrm{CO}_{2}$ and the transpiration rate of the stomata by $\mathrm{Pb}$ led to a decrease in the water use efficiency (WUE), which refers to the ratio of water used in plant metabolism to water lost by the plant through transpiration. The present study showed that $\mathrm{Pb}$ stress applied at $1 \mathrm{~g} / \mathrm{kg} \mathrm{Pb}$-treated soil had caused drop in WUE and RWC. Sharma and Dubey (2005) reported the same response on WUE and RWC in Lathyrus sativus $L$. due to $\mathrm{Pb}$ exposure. RWC decrement indicates that the excess concentrations of $\mathrm{Pb}$ affect root growth by decreasing the formation of root hairs and causing structural changes thus affecting water flow into and within roots, which reduces water uptake and its transport 
to the shoot (Kastori et al. 1992). The limited effect of $\mathrm{Pb}$ on WUE and RWC (up to $1 \mathrm{~g} / \mathrm{kg}$ of soil) indicated that $A$. auriculiformis tolerates the presence of $\mathrm{Pb}$ by controlling water loss (15\% compared to the control). This effect may result from effective stomatal regulation in cells turgidity (Chandra et al., 2016). To maintain this turgidity, plants trigger other tolerance mechanisms that contribute to the adaptation of osmotic and ionic stress caused by metals, and allow the internal osmotic pressure to be adjusted due to electrolytes and organic solutes mainly from soluble sugars and amino acids, such as proline (Taji et al., 2004; Denden et al., 2005).

When the oxidative stress is too high and outstrips the antioxidant capacity, excess radicals cause damage to plant molecules leading to a disruption of many physiological processes such as photosynthesis and respiration (Cecchi, 2008; Agati et al., 2012). At this point, the appearance of visible symptoms take place, such as browning of the roots, as well as chlorosis and necrosis on the leaves, leading to a disruption of growth that can even lead to the death of the organism. Proline is the most important amino acid that accumulates under heavy metals stress. Hence, proline accumulations in plants grown in $1 \mathrm{~g} / \mathrm{kg}$ and $2 \mathrm{~g} / \mathrm{kg}$ Pb-treated soil proves that $A$. auriculiformis has a high tolerance potential against $\mathrm{Pb}$ toxicity because proline plays three major roles under metal stress; (i) acting as an excellent osmolyte, (ii) as a metal chelator (Ashraf and Foolad, (2007), and (iii) inhibitor of lipid peroxidation, thus protecting plants from oxidative stress and plays a key role in heavy metal tolerance (Ullah et al. 2019). Even though proline is not the only defences involve since total antioxidant activities were not correlated to their phenolic and flavonoid contents (Hamli et al. 2017), plants with high proline accumulation were able to tolerate or accumulate a higher concentration of metals (Ahmad et al., 2015). In the present study, the phytoremedial potential of A. auriculiformis plants was assessed by the CAT enzyme content, which is considered as a defence mechanism that allows the plant to combat this damage. The increment in the CAT enzyme in the plants are grown in 1 and $2 \mathrm{~g} / \mathrm{kg}$ $\mathrm{Pb}$-treated soil provides a piece of evidence that $A$. auriculiformis has a good antioxidant defence system to tolerate $\mathrm{Pb}$ stress, which is a powerful tool for the survival of metal accumulating plants (Habiba et al., 2015). Catalase enzyme acts as an antioxidant against the reactive oxygen species (Nayana and Malode, 2012). Hence, when cells are in stress condition, they will generate $\mathrm{H}_{2} \mathrm{O}_{2}$ through emergency catabolic processes, but CAT will degrade $\mathrm{H}_{2} \mathrm{O}_{2}$ and result in a net gain of reducing equivalents (Afshan et al., 2015).

However, when the capacity of antioxidant processes and detoxification mechanisms are lower than the reactive oxygen species (ROS) production, which was noted in $A$. auriculiformis seedlings grown in $3 \mathrm{~g} / \mathrm{kg} \mathrm{Pb}$-treated soil, plant damage occurs. High levels of ROS cause inactivation of certain enzymes, decrease enzyme synthesis or change the assembly of enzyme subunits resulting in a reduction in CAT activity, thereby longer $\mathrm{H}_{2} \mathrm{O}_{2}$ action, which leads to cell disturbances and DNA damage (Lo et al., 2011). Acacia auriculiformis showed high accumulation in proline and CAT enzyme content in plants grown in $1 \mathrm{~g} / \mathrm{kg}$ and $2 \mathrm{~g} / \mathrm{kg}$ Pb-treated soil to face the overproduction of ROS and the oxidative stress induced by the metal. This finding gave strong evidence of
A. auriculiformis plant tolerance characteristic, which makes it a potential phytoremediation agent to resist and absorb $\mathrm{Pb}$ from the soil. Still, A. auriculiformis plant exposed to $3 \mathrm{~g} / \mathrm{kg} \mathrm{Pb}$ resulted in a lower accumulation in proline and CAT enzyme which adversely affect the plant resistance to oxidative stress by the inhibition of cytoplasmic enzymes and damage the structures of a cell (Asati et al., 2016).

The $\mathrm{Pb}$ concentration in the soil had appreciable effects on $\mathrm{Pb}$ accumulation in A. auriculiformis plant tissues, and as the concentration of $\mathrm{Pb}$ increased, the transport of $\mathrm{Pb}$ from the root to different plant parts decreased in the following order: root $>$ shoot $>$ leaves. The findings pertaining to the $\mathrm{Pb}$ uptake in this study agree with John et al. (2009) study on Brassica juncea roots, as roots are directly subjected to $\mathrm{Pb}$ contamination and act as barriers to apoplastic and symplastic $\mathrm{Pb}$ transport. Hence, $\mathrm{Pb}$ translocation to the aerial part of the plant is disturbed (Page and Fuller, 2015). This may be due to a decrement in lignified cells and xylem vessels, which can be explained by occlusion of the xylem vessels (Dugé de Bernoville, 2009). The phenomena of vascular occlusion are the deposition of a fibrous polysaccharide material, which is the origin of the formation of plugs in the xylem, preventing water supply and consequently, reduction in the vessel's lumen diameter. This obstruction is a defensive reaction of the plant to prevent the flux of $\mathrm{Pb}$ which follows the water movement in the plant (Dugé de Bernoville, 2009) and that explains the reduction in the water content observed in Table 4.1. Vessel occlusion has been reported as plant response under metal stress in Vicia sativa (Pérez-de-Luque et al., 2006).

According to Wierzbicka, (1987) only a small fraction of $\mathrm{Pb}$ presented in the root will be transferred to the aerial parts because more than $90 \%$ is found in insoluble form and strongly bound to the outer cellular envelopes. In the present study, $20 \%$ and $14 \%$ of $\mathrm{Pb}$ absorbed by $A$. auriculiformis plants were translocated to the areal parts in $1 \mathrm{~g} / \mathrm{kg}$ and $2 \mathrm{~g} / \mathrm{kg} \mathrm{Pb}$-treated soil, respectively. This limited transport from roots to leaves was caused by the barrier formed by the root endoderm where casparian strip bands is the major factor restricting the movement of $\mathrm{Pb}$ from the endoderm to the central cylinder (Sharma and Dubey 2005),. This restriction of transport to aerial parts represents a tolerance factor for some plants to the presence of contaminants in their growing medium, and it is important for their survival where only a small portion of $\mathrm{Pb}$ absorbed and transferred to the leaves, as $\mathrm{Pb}$ is a toxic element for photosynthetic activity, chlorophyll and antioxidant enzymes synthesis (Kim et al., 2003).

The competition on the sorption place between $\mathrm{Pb}$ ions and the macronutrients in the roots surface especially those with the same valency such as $\mathrm{N}, \mathrm{P}$, and $\mathrm{K}$ which affects their absorption (Küpper and Kochian, 2010). Therefore, $\mathrm{Pb}$ will interfere with nutrient uptake by affecting membrane transport processes and altering the permeability of the plasma membrane (Dong et al., 2006). When $\mathrm{Pb}$ attaches to membrane wall components in large quantities, it changes the physical and chemical properties of the wall, and its plasticity. This plasticity reduction affects many cellular mechanisms such as cell division and elongation, which affects the proper functioning of plant cells (Pourrut, 2008). As shown in Figure 2, the symptoms of high $\mathrm{Pb}$ toxicity in $A$. auriculiformis plants were 
expressed by growth inhibition, particularly root growth, by reducing the absorption of water and similarly the absorption of essential nutrients, such as $\mathrm{N}, \mathrm{P}$, and $\mathrm{K}$ which play a significant role in the metabolism of plants including chlorophyll synthesis, protein analysis, stem and root growth, and enzyme cofactors associated with metabolites transport (Tripathi et al., 2014).

The crucial factors determining A. auriculiformis phytoremediation either as phytostabilisation or phytoextraction may lie in the translocation process of $\mathrm{Pb}$ from the roots to the areal parts. According to BongouaDevisme et al. (2019), TF and BFC value will determine the type of phytoremediation agent either as phytoextraction (TF and BCF $>1$ ) or phytostabilisation (TF and BCF <1) or phytostabiliser but act as phytoextract at lower concentrations (BCF $>1$ and $\mathrm{TF}<1$ ). Oseni et al. (2018) reported herbaceous plant, Sida acuta and Chromolaena odorata only managed to exhibit TF value at 0.9 and 0,7 respectively with most of extracted $\mathrm{Pb}$ stored in the roots system. Thus, both plants can only be considered as phytostabilisations agent since the Tf value was less than 1 . In the present study, the BCF and TF in 1 $\mathrm{g} / \mathrm{kg} \mathrm{Pb}$ treatments were higher than 1 . The high tolerance of $A$. auriculiformis shown previously in growth result, with the BCF and TF greater than 1 makes it an excellent candidate to phytoextract $\mathrm{Pb}$ from the soil. However, BCF and $\mathrm{TF}$ decreased with the increment of $\mathrm{Pb}$ concentration as increasing the concentration of $\mathrm{Pb}$ to $2 \mathrm{~g} / \mathrm{kg}$ and $3 \mathrm{~g} / \mathrm{kg}$ Pb-treated soil hampered normal physiological and metabolic activities. Subsequently A. auriculiformis avoids translocation of this metal by the implementation of several mechanisms to reduce the transfer of $\mathrm{Pb}$ to the aerial part of the plant. This is an important protective mechanism against the spread of this toxic metal to green tissue (Sinha et al., 2013). Majid et al., (2012) observed a BCF of 1.02 and a TF of 1.89 in A. mangium grown in a sewage sludge containing only $19.2 \mathrm{ppm}$ of $\mathrm{Pb}$. However, the concentrations of metals experimented in the media are very low compared to the present study, where $A$. auriculiformis plants grown in $1 \mathrm{~g} / \mathrm{kg}$ Pb-treated soil showed high tolerance, absorbed $0.64 \mathrm{~g}$ in their roots and translocated $0.38 \mathrm{~g}$ to the shoots. With the BCF and TF more than 1, A. auriculiformis could be a perfect phytoremediation candidate as a $\mathrm{Pb}$ phytoextractor in a contaminated soil with no more than $1 \mathrm{~g} / \mathrm{kg} \mathrm{Pb}$. Although increasing $\mathrm{Pb}$ concentration to $2 \mathrm{~g} / \mathrm{kg}$ of soil reduced and hampered different plant morphological and physiological functions, A. auriculiformis plants were able to grow and absorb $0.97 \mathrm{~g}$ of $\mathrm{Pb}$ in its roots; thus it can be used as a phytostabilizer in a $2 \mathrm{~g} / \mathrm{kg} \mathrm{Pb}$ contaminated soil.

\section{Conclusion}

Lead accumulation induced both physiological and biochemical changes in A. auriculiformis with $\mathrm{Pb}$ tolerance proportional to the increased of $\mathrm{Pb}$ concentrations and significantly increased level of antioxidative enzymes (catalase). The results demonstrated that $A$. auriculiformis can tolerate $\mathrm{Pb}$ toxicity up to $2 \mathrm{~g} / \mathrm{kg} \mathrm{Pb}$ of soil, and hyperaccumulate a significant amount of $\mathrm{Pb}$ content in roots and shoots through phyto stabilisation and phyto-extraction.

\section{Acknowledgment}

The authors would like to thank the Ministry of Higher Education, Malaysia and Universiti Putra Malaysia for the financial support through FRGS Grant no. FRGS/1/2016/STG03/UPM/202/8 and all staff of the Plant Systematic and Microbe Laboratory, Biology Department, Universiti Putra Malaysia for all their continuous efforts and contributions. in one way or another.

\section{References}

Abuye C, Urga K, Knapp H, Selmar D, Omwega AM, Imungi JK, and Winterhalter P. 2003. A compositional study of Moringa stenopetala leaves. J. East Afr. Med, 80: 247-252.

Adhikari T, Kumar A, Singh MV and Rao AS. 2014. Phytoaccumulation of lead by selected wetland plant species. Commun. Soil Sci. Plant Anal. 41: 2623-2632.

Afshan S. Ali S, Bharwana SA, Rizwan M, Farid M, Abbas M, Ibrahim F, Mehmood MA and Abbasi GH. 2015. Citric acid enhances the phytoextraction of chromium, plant growth and photosynthesis by alleviating the oxidative damages in Brassica napus L. Environ. Sci. Pollut. Res. 22: 11679-11689.

Agati G, Azzarello E, Pollastri S and Tattini M. 2012. Flavonoids as antioxidants in plants: location and functional significance. Plant Sci. 196: 67-76.

Ahmad A, Hadi F and Ali N. 2015. Effective phytoextraction of cadmium (Cd) with increasing concentration of total phenolics and free proline in Cannabis sativa $(L)$ plant under various treatments of fertilizers, plant growth regulators and sodium salt. Int J Phytoremediation. 17: 56-65.

Ahmad Zuhaidi Y and Jeyanny V. 2018. Phytoremediation of heavy metals using Acacia mangium in Rahman Hydraulic Tin (RHT) tailings, Klian Intan, Malaysia. Adv. Plant Agri. Res. 8: 247-249

Ahmad Zuhaidi Y, Jeyanny Y, Fakhri MI and Wan Rasidah K. 2018. Reversing soil degradation via phytoremediaton techniques in an ex-tin mine and gold mine in Peninsular Malaysia. Pp 686691 Proceeding Global Symposium of Soil Pollution, 2-4 May 2018. Rome, Italy

Ali A, Iqbal N, Ali F, Afzal B and Nicholson G. 2012. Alternanthera bettzickiana (Regel) a potential halophytic ornamental plant. Growth Physiol. Adapt. Flora. 20: 318-321.

Ali H, Khan E and Sajad MA. 2013. Phytoremediation of Heavy Metals-Concepts and Applications. Chemosphere. 91: 869-881.

Asati S, Pichhode M and Nikhil K. 2016. Effect of Heavy Metals on Plants: An Overview. Int J App Inno Engin Management. 5: 2319-4847.

Ashraf M and Foolad MR. 2007. Roles of glycine betaine and proline in improving plant abiotic stress resistance. Environ. Exp. Bot. 59: 206-216.

Bongoua-Devisme AJ, Akotto OF, Guety T, Kouakou SAAE, Ndoye F and Diouf D. 2019. Enhancement of phytoremediation efficiency of Acacia mangium using earthworms in metalcontaminated soil in Bonoua, Ivory Coast. African J Biotech 18: 622-631.

Chatterjee J, and Chatterjee C. 2003. Management of phytotoxicity of cobalt in tomato by chemical measures. Plant Sci. 64: 793-801.

Cecchi M. (2008). Devenir du plomb dans le système Sol-Plante: Cas d'un sol contaminé parune usine de recyclage du plomb et de deux plantes potagères (Fève et Tomate). $\mathrm{PhD}$ thesis. Institut National Polytechnique de Toulouse. France 
Chandra R. and Kang H. 2016. Mixed heavy metal stress on photosynthesis, transpiration rate, and chlorophyll content in poplar hybrids. Forest Sci. Technol. 12: 55-61.

Del Rio CM, Font R, Moreno-Rojas R and De Haro-Bailon A. 2006. Uptake of lead and zinc by wild plants growing on contaminated soils. Ind Crop Prod. 24: 230-237.

Denden M, Bettaieb T, Salhi A and Mathlouthi M. 2005. Effet de la salinité sur la fluorescence chlorophyllienne, la teneur en proline et la production florale de trois espèces ornementales, Tropicultura, 23: 220-225.

Dong J, Wu F and Zhang G. 2006. Influence of cadmium on antioxidant capacity and four microelement concentrations in tomato seedlings (Lycopersicon esculentum). Chemosphere. 64: 1659-1666.

Dugé de Bernonville, T. 2009. Caractérisations histologique, moléculaire et biochimique des interactions compatible et incompatible entre Erwinia amylovora, agent du feu bactérien, et le pommier (Malus $x$ domestica). PhD Thesis. University of Angers, Fance.

Habiba U, Ali S, Farid M, Shakoor MB, Rizwan M, Ibrahim M, Abbasi GH, Hayat T and Ali B. 2015. EDTA enhanced plant growth, antioxidant defense system and phytoextraction of copper by Brassica napus L. Environ. Sci. Pollut. Res. 22 : 1534-1544.

Hamli S, Kadi K, Addad D and Bouzerzour H. 2017. Phytochemical Screening and Radical Scavenging Activity of Whole Seed of Durum Wheat (Triticum durum Desf.) and Barley (Hordeum vulgare L.) Varieties. Jordan J Bio Sci. 10: 323-327

Huang J, Qin F, Zang G, Kang Z, Zou H, Hu F, Yue C, Li X and Wang G. 2013. Mutation of OsDET1 increases chlorophyll content in rice. Plant Sci 210: 241-249.

Illié ZS, Mirecki N, Trajkovic R, Kapoulas N, Milenkovic L and Sunic L. 2015. Effect of $\mathrm{Pb}$ on germination of different seed and his translocation in bean seed tissues during sprouting. Fresenius Environ Bull. 24: 670-75.

John R, Ahmad P, Gadgil K and Sharma S. 2009. Heavy metal toxicity: Effect on plant growth, biochemical parameters and metal accumulation by Brassica juncea L. Int J Plant Prod. 3: 6576.

Kanwal U, Ali S, Shakoor MB, Farid M, Hussain S, Yasmeen T, Adrees M, Bharwana SA and Abbas F. 2014. EDTA ameliorates phytoextraction of lead and plant growth by reducing morphological and biochemical injuries in Brassica napus L. under lead stress. Environ. Sci. Pollut. Res. 21: 9899-9910.

Kastori R, Petrović M and Petrović N. 1992. Effect of excess lead, cadmium, copper, and zinc on water relations in sunflower. $J$ Plant Nut 15: 2427-2439

Kim YY, Yang YY and Lee Y. 2003. Pb and Cd uptake in rice roots. Physiol Plant. 116: 368-372.

Küpper H and Kochian LV. 2010. Transcriptional regulation of metal transport genes and mineral nutrition during acclimatization to cadmium and zinc in the $\mathrm{Cd} / \mathrm{Zn}$ hyperaccumulator, Thlaspi caerulescens (Ganges population). New Phytol. 185: 114-129.

Liu X, Mak M, Babla M, Wang F, Chen G, Veljanoski F, Wang G, Shabala S, Zhou M and Chen Z. 2014. Linking stomatal traits and expression of slow anion channel genes HvSLAH1 and HvSLAC- 1with grain yield for increasing salinity tolerance in barley. Front Plant Sci. 5:1-12

Lo IMC, Tsang DCW, Yip TCM, Wang F and Zhang W. 2011. Influence of injection conditions on EDDS-flushing of metalcontaminated soil. J Hazard Mater. 192: 667-675.

Magné C and Larher F. 1992. High sugar content of extracts interferes with colorimetric determination of amino acids and free proline. Anal. Biochem. 200:115-118.
Mahdavi A, Khermandar K, Asbchin SA and Tabaraki R. 2014. Lead Accumulation Potential in Acacia victoria. Int $J$ Phytomerediation. 16: 582-592

Majid NM, Islam MM and Mathew L. 2012. Heavy metal uptake and translocation by mangium (Acacia mangium) from sewage sludge contaminated soil. Aust J Crop Sci 6:1228- 1235.

Masvodza DR, Dzomba P, Mhandu F and Masamha B. 2013. Heavy Metal Content in Acacia saligna and Acacia polyacantha on Slime Dams: Implications for Phytoremediation. Am J Exp Agri. 3: 871-883.

McGrath SP and Cunliffe CH. 1995. A simplified method for the extraction of the metals in sewage sludge on soils, microorganisms and plants. J. Ind. Microbiol. 14: 94-104.

Meriem L, Baghdad B, El Hadi D and Bouabdli A. 2015. Phytoremediation Mechanisms of Heavy Metal Contaminated Soils: A Review. Open J Ecol. 5:375-88.

Mohd SN, Majid N M, Shazili N A M and Abdu A. 2013. Growth performance, biomass and phytoextraction efficiency of Acacia mangium and Melaleuca cajuputi in remediating heavy metal contaminated soil. Am J Environ Sci 9: 310-316.

Moosavi SG and Seghatoleslami MJ. 2013. Phytoremediation: A Review. Adv Agri Biol 1: 5-11

Muhammad S, Iqbal MZ and Mohammad A. 2008. Effect of lead and cadmium on germination and seedling growth of Leucaena leucocephala. J. Appl. Sci. Environ. 12: 61 - 66.

Nayana S and Malode SN. 2012. Phytoremediation Potential of Cassia Tora (L.), Roxb. to remove heavy metals from Waste soil, collect from sukali compost and landfill depot, amravati (M.S.). Global J Bio-Sci Biotech 1: 104-109

Ochonogor RO and Atagana HI. 2014. Phytoremediation of Heavy Metal Contaminated Soil by Psoralea pinnata. Int $J$ Environ Sci Dev. 5: 440-443.

Oseni OM, Dada OE, Okunlola GO and Ajo AA. 2018. Phytoremediation Potential of Chromolaena odorata (L.) King and Robinson (Asteraceae) and Sida acuta Burm. f. (Malvaceae) Grown in lead-Polluted Soils. Jordan J Bio Sci. 11: 355-360

Page V and Feller U. (2015). Heavy Metals in Crop Plants: Transport and Redistribution. Agronomy. 5: 447-463.

Pan X, Zhang D, Chen X, Bao A and Li L. 2011. Antimony accumulation, growth performance, antioxidant defense system and photosynthesis of Zea mays in response to antimony pollution in soil. Water Air Soil Pollut. 21: 517-523.

Pereira LB, Tabaldi LA, Goncalves JF, Jukoski JO and Pauletto MM. 2006. Effect of aluminium on inolevulinic acid dehydratase (ALAD) and the development of cucumber (Cucumis sativus). Environ Exp Bot. 57: 106-115.

Pérez-de-Luque A, Lozano-Baena MD, Prats E, Moreno MT and Rubiales D. 2006. Medicago truncatula as a Model for Nonhost Resistance in Legume-Parasitic Plant Interactions. Plant Physiol. 145: 2437-449.

Pike S M, Ádám A L, Pu X A, Hoyos ME, Laby R, Beer SV and Novacky A. 1998. Effects of Erwinia amylovora harpin on tobacco leaf cell membranes are related to leaf necrosis and electrolyte leakage and distinct from perturbations caused by inoculated E. amylovora. Physiol Mol Plant Pathol. 53: 39-60.

Pourrut B, Shahid M, Dumat C, Winterton P and Pinelli EB. 2011. Lead uptake, toxicity, and detoxification in plants. Rev Environ Contam Toxicol. 213:113-36.

Pourrut B, Perchet G, Silvestre J, Cecchi M, Guiresse M and Pinelli E. 2008. Potential role of NADPH-oxidase in early steps of lead-induced oxidative burst in Vicia faba roots. J Plant Physiol. 165: 571-579 
Scippa G, Di-Michele M, Onelli NE, Patrignani G, Chiatante D. and Bray E. 2004. The histone-like protein H1-S and the response of tomato leaves to water deficit. J Exp Bot. 55: 99-109.

Sharma P and Dubey RS. 2005. Lead toxicity in plants. Braz $J$ Plant Physiol. 17:35-52.

Sofea A, Zerkout A, Nor Azwady AA, Rusea G and Muskhazli M. 2017. Assessment of Acacia auriculiformis Cunn. Ex Benth. Seed Germination and Growth Resistance towards Arsenic Toxicity. Annu Res Rev Biol. 18: 1-10.

Souza LA, Fernando AP, Roberta CN and Ricardo AA. 2013. Use of Non-Hyperaccumulator Plant Species for the Phytoextraction of Heavy Metals Using Chelating Agents. Sci. Agric. 4: 290-95.

Sinclair TR, Tanner CB and Bennett JM. 1984. Water use efficiency in crop production. BioScience. 34: 36-40.

Sinha S, Mishra RK, Sinam G, Mallick S and Gupta AK. 2013. Comparative Evaluation of Metal Phytoremediation Potential of Trees, Grasses and Flowering Plants from Tannery Wastewater Contaminated Soil in Relation with, Physico-Chemical Properties. Soil Sediment Contam. 22: 958-983.

Silvana RO, José AGN, Joaquim AN and Bradley TJ. 2010. Determination of macro- and micronutrients in plant leaves by high-resolution continuum source flame atomic absorption spectrometry combining instrumental and sample preparation strategies. Spectrochim Acta Part B. 65: 316-320.

Srinivas TNR, Kailash TB and Anil KP. 2013. Silanimonas mangrovi sp. nov., a member of the family Xanthomonadaceae isolated from mangrove sediment, and emended description of the genus Silanimonas. Int. J. Syst. Evol. Microbiol. 63: 274-279.

Taji T, Seki M, Satou M, Tetsuya S, Masatomo K, Kanako I, Yoshihiro N, Mari N, Jian-Kang Z and Kazuo S. 2004 Comparative genomics in salt tolerance between Arabidopsis and aRabidopsis-related halophyte salt cress using Arabidopsis microarray. Plant Physiol. 135:1697-1709.
Tang Q, Lin LX, Yu ZX, Yi H and Hua Y. 2008. Effects of plumbum and chromium stress on the growth of tea plants. Southwest China J Agri Sci. 21:156-162.

Tripathi DK, Singh VP, Chauhan DK, Prasad SM and Dubey NK. 2014. Role of macronutrients in plant growth and acclimation: recent advances and future prospective. In: Ahmad P, Wani MR, Azooz MM and Tran LSP (Eds.). Improvement of crops in the era of climatic changes. Springer, New York, pp 197-216

Troll W and Lindsey J. 1955. A photometric method for the determination of proline. J Biol Chem 215: 655-660

Turnbull JW, Midgley SJ and Cossalter C. 1997. Tropical Acacias planted in Asia: an overview of recent developments in Acacias planting. In: Turnbull, J.W., et al. (Eds.) Proceedings of Recent Developments in Acacia Planting. Australia Center of International Agriculture Research. Hanoi.

Ullah R, Hadi F, Ahmad S, Jan AU and Rongliang Q. 2019. Phytoremediation of Lead and Chromium Contaminated Soil Improves with the Endogenous Phenolics and Proline Production in Parthenium, Cannabis, Euphorbia, and Rumex Species. Water Air Soil Poll. 230: 40

Veronica J, Majid NM, Islam MM and Arifin A. 2011. Assessment of heavy metal uptake and translocation in Acacia mangium for phytoremediation of cadmium contaminated soil. $J$ Food Agric Environ. 9: 588-592.

Weydert CJ and Cullen JJ. 2009. Measurement of superoxide dismutase, catalase, and glutathione peroxidase in cultured cells and tissue. Nat Protoc. 5: 51-66.

Wierzbicka M. (1987). Lead translocation and localization in Allium cepa roots. Can J Bot. 65: 1851-1860.

Zerkout A, Omar H, Ibrahim MH and Muskhazli M. 2018. Influence of Lead on In vitro Seed Germination and Early Radicle Development of Acacia auriculiformis Cunn. Ex Benth Species. Annu Res Rev Biol. 28: 1-12. 